\title{
Korelasi antara Gambaran Spektral Doppler Arteri Tibialis Posterior dan Arteri Dorsalis Pedis dengan Skor PEDIS pada Penderita Ulkus Kaki Diabetik
}

\author{
${ }^{1}$ Leise Limpeleh, ${ }^{2}$ Richard Sumangkut, ${ }^{3}$ Djoni E. Tjandra
}

\author{
${ }^{1}$ PPDS Ilmu Bedah Fakultas Kedokteran Universitas Sam Ratulangi Manado \\ ${ }^{2}$ Divisi Bedah Vaskuler Bagian Ilmu Bedah Fakultas Kedokteran Universitas Sam Ratulangi \\ Manado \\ Email: leiselimpeleh@ hotmail.com
}

\begin{abstract}
Diabetic foot ulcer is still a major health problem worldwide due to its increasing prevalence. This study was aimed to prove the correlation between PEDIS score and vascular Doppler examination performed on dorsalis pedis and posterior tibial arteries of patients with diabetic foot ulcers. This was an observational study with a cross sectional design. The results showed that during the period of August 2017 until January 2018, there were 62 patients with diabetic foot ulcers at the wards of Surgery Department and Internal Medicine Department of Prof. Dr. R. D. Kandou Hospital Manado. Most patients were in the age group of 60-69 years, had leukocytosis $(74.1 \%)$, poor blood sugar control (70.9\%), and hypoalbuminemia (98.3\%). Moreover, smoking history in $20.9 \%$ of patients; hypertension in $35.4 \%$ of patients; and dyslipidemia in $20.9 \%$ of patients. The Doppler examination resulted in biphasic waveform in posterior tibial artery $(40.3 \%)$ as well as in dorsalis pedis artery $(41.9 \%)$. Perfusion score showed $50 \%$ of subjects had PAD. Most subjects $\left(90.3 \%\right.$ ) had ulcers of $>3 \mathrm{~cm}^{2}$ and were infected superficially in the subcutaneous area (56.4\%). Most subjects (58\%) suffered from severe infection with high leucocyte counts, however, only $29 \%$ of subjects had lost of sensoric ability. The correlation Spearman test obtained $\mathrm{r}=-0.486$ and $P=0.000$ in the posterior tibial artery; and $\mathrm{r}=$ 0.281 and $P=0.0027$ in the dorsalis pedis artery. Conclusion: There was a significant correlation between vascular Doppler result and PEDIS score. The higher the PEDIS score, the worse the vascular Doppler result.
\end{abstract}

Keywords: diabetic foot ulcer, PEDIS score, vascular Doppler

\begin{abstract}
Abstrak: Ulkus kaki diabetik masih merupakan masalah kesehatan utama sedunia dengan prevalensi yang terus meningkat. Penelitian ini bertujuan untuk membuktikan apakah terdapat hubungan antara skor PEDIS dan pemeriksaan spektral Doppler vaskuler pada arteri poplitea, dorsalis pedis, dan tibialis posterior pada pasien dengan ulkus kaki diabetik. Jenis penelitian ialah observasional dengan desain potong lintang. Hasil penelitian mendapatkan 62 pasien dengan ulkus kaki diabetik di bangsal Bagian Bedah dan Penyakit Dalam RSUP Prof. Dr. R. D. Kandou Manado selama periode Agustus 2017 sampai Januari 2018. Ukus diabetik tersering ditemukan pada kelompok usia 60-69 tahun dengan rerata usia 58,5 tahun. Sebagian besar pasien mengalami leukositosis $(74,1 \%)$, kontrol gula darah buruk $(70,9 \%)$, dan hipoalbuminemia $(98,3 \%)$. Riwayat merokok didapatkan sebesar 20,9\%; hipertensi 35,4\%; dan dislipidemia 20,9\%. Hasil pemeriksaan Doppler bifasik pada arteri tibialis posterior $(40,3 \%)$ dan arteri dorsalis pedis $(41,9 \%)$. Skor perfusi menunjukkan 50\% subyek mengalami penyakit arteri perifer (PAD). Sebagian besar (90,3\%) subjek memiliki ulkus $>3 \mathrm{~cm}^{2}$ luas area. Infeksi sebagian besar superfisial di subkutan $(56,4 \%)$, selebihnya menderita infeksi hingga fasia, otot, dan tendon. Sebagian besar subyek penelitian menderita infeksi berat (58\%) dengan angka leukosit tinggi. Hanya 29\% dari subjek penelitian mengalami kehilangan kemampuan sensorik. Hasil uji korelasi Spearman mendapatkan pada arteri tibialis posterior: $\mathrm{r}=-0,486$ dengan $P=0,000$ dan pada arteri dorsalis pedis: $\mathrm{r}=-0,281$ dengan $P$ $=0,0027$. Simpulan: Terdapat hubungan bermakna antara hasil pemeriksaan spektral Doppler dan skor PEDIS. Semakin tinggi skor PEDIS semakin buruk hasil spektral Doppler.
\end{abstract}

Kata kunci: ulkus kaki diabetik, skor PEDIS, Doppler spektral vaskular 
Sampai saat ini ulkus kaki diabetik masih menjadi masalah kesehatan utama di seluruh dunia karena jumlah kasus yang semakin meningkat. Ulkus bersifat kronis, sulit sembuh, telah mengalami infeksi, serta iskemia dengan risiko amputasi yang mengancam nyawa dan membutuhkan sumber daya kesehatan yang besar yang akan memberikan beban sosio-ekonomi bagi pasien, masyarakat, dan negara. Berbagai metode pengobatan telah dikembangkan namun sampai saat ini belum ada yang dapat memberikan hasil memuaskan.

Ulkus diabetik merupakan salah satu penyebab paling banyak, paling berat, dan menghabiskan biaya terbanyak untuk biaya rawat inap. ${ }^{1,2}$ Keterlambatan sembuhnya ulkus pada kaki diabetik dapat menyebabkan perlunya dilakukan amputasi yang kemudian mengurangi kualitas hidup pasien dan meningkatkan mortalitas. ${ }^{3-7}$

Indonesia merupakan salah satu dari 10 negara dengan populasi diabetes melitus (DM) terbesar di dunia. Populasi DM di Indonesia tersebar baik di kota maupun di pedesaan. International Diabetes Federation (IDF) melaporkan tahun 2013 terdapat 5,6 juta penderita DM dan diprediksi akan meningkat menjadi 6,7 juta di tahun $2035{ }^{7}$

Salah satu komplikasi makrovaskular DM ialah ulkus kaki diabetik. Sayangnya, tidak begitu banyak laporan penelitian yang berhubungan dengan ulkus kaki diabetik di Indonesia. Riset awal peneliti menunjukkan prevalensi ulkus kaki diabetik di Indonesia sebanyak $25 \%$ di rawat jalan. ${ }^{7-9}$ Tingginya prevalensi ini menjadi bukti empiris perlunya upaya sistematis dalam penatalaksanaan ulkus kaki diabetik di Indonesia., ${ }^{4,10,11}$

Banyaknya persoalan klinis yang perlu dijawab dengan metode ilmiah yang sistematik mengharuskan dibuatnya penelitian dan publikasi dalam menjawab persoalan klinis seputar ulkus kaki diabetik. Oleh karena itu sangat penting adanya suatu pendekatan yang standar dan efisien untuk merawat kaki diabetik dengan waktu yang sesingkat mungkin. Langkah pertama yang dilakukan yaitu mengidentifikasi tingkat keparahan risiko terjadinya ulkus pada semua pasien dengan kaki diabetik. ${ }^{8,11,12}$
WHO merekomendasikan klasifikasi PEDIS sebagai sarana penegakan diagnosis dan membantu menentukan tatalaksana kaki diabetik. Sistem klasifikasi PEDIS mencakup variabel relevan dan berguna dalam praktik klinis dan penelitian baik untuk mengantisipasi biaya perawatan kesehatan dan untuk membandingkan subkelompok pasien. ${ }^{10,13,14}$

Evaluasi penyakit arteri perifer (PAP) dengan pemeriksaan Doppler vaskuler dapat menjadi dasar diagnosis, penentuan terapi, dan evaluasi terapi yang diberikan. Pemeriksaan Doppler vaskuler dapat memberi informasi berat ringannya stenosis dengan mendengar bentuk gelombang aliran darah pada arteri. Penyakit arteri perifer yang terjadi pada pasien DM paling sering melibatkan pembuluh darah mulai dari arteri poplitea ke arah distal. ${ }^{15}$

Handheld vascular Doppler merupakan modalitas yang mudah tersedia dan non invasif untuk evaluasi arteri ekstremitas inferior dan dapat mendeteksi tingkat keparahan gangguan aliran darah atau PAP dengan sensitivitas $42,8 \%$ dan spesifisitas 97,5\%. Kelebihan alat ini dibandingkan USG Doppler, yaitu mudah dibawa kemana saja dan harganya jauh lebih murah namun kelemahannya yaitu hanya dapat mendengarkan gambaran spektral atau waveform dari pembuluh darah, yaitu trifasik, bifasik, dan monofasik yang menunjukkan derajat stenosis dari suatu pembuluh darah. ${ }^{15-17}$

Pada penelitian ini dianalisis apakah terdapat korelasi antara gambaran spektral Doppler vaskular ekstremitas inferior pada arteri dorsalis pedis dan arteri tibialis posterior dengan skor PEDIS pada penderita ulkus kaki diabetik di RSUP Prof. Dr. R. D. Kandou Manado.

Diharapkan hasil penelitian ini dapat menunjang penggunaan handheld vascular Doppler dalam membantu penentuan terapi dan pengobatan pada pasien ulkus kaki diabetik khususnya di RS daerah dengan keterbatasan fasilitas canggih seperti USG Doppler serta menambah kegunaan sistem klasifikasi PEDIS dalam praktik klinis sehari-hari. ${ }^{11,15-17}$ 


\section{METODE PENELITIAN}

Jenis penelitian ini ialah observasional dengan desain potong lintang. Penelitian dilakukan di Bagian Bedah dan Bagian Penyakit Dalam Rumah Sakit Umum Pusat Prof. Dr. R. D. Kandou Manado dan dilaksanakan pada bulan Agustus 2017 sampai Januari 2018. Subyek penelitian ialah pasien ulkus kaki diabetik yang dirawat di RSUP Prof. Dr. R. D. Kandou Manado serta memenuhi kriteria inklusi dan eksklusi.

Kriteria inklusi dalam penelitian ini ialah: pasien ulkus kaki diabetik, keadaan pasien memungkinkan untuk pemeriksaan Doppler, bersedia untuk diikutkan dalam penelitian ini dan memenuhi aturan-aturan penelitian sedangkan kriteria eksklusi ialah pasien dengan keganasan, koagulopati, peripheral vascular disease (PVD) yang lain, menggunakan obat-obatan vasodilator atau vasokonstriktor, menolak ikut serta dalam penelitian, belum/tidak jelas diagnosisnya, atau sudah menjalani amputasi mayor pada tungkai yang diperiksa.

Besar sampel dihitung berdasarkan rumus single mean dan didapatkan jumlah sampel 61,5 yang dibulatkan 62 pasien. Variabel penelitian ialah temuan spektral Doppler dan keparahan ulkus penderita kaki diabetik (skor PEDIS). Analisis data hubungan pulse wave Doppler dengan keparahan ulkus sesuai klasifikasi PEDIS menggunakan skala ordinal dan dilakukan uji statistik menggunakan analisis nonparametrik dengan Spearman's rho.

\section{HASIL PENELITIAN}

Dalam periode Agustus 2017 sampai Januari 2018, terdapat 62 pasien ulkus kaki diabetik yang memenuhi kriteria inklusi dan menjadi sampel penelitian di ruang rawat inap Bagian Bedah dan ruang rawat inap Bagian Penyakit Dalam RSUP Prof. Dr. R. D. Kandou Manado.

Tabel 1 memperlihatkan bahwa pasien ulkus kaki diabetik berjenis kelamin lakilaki (36 orang) lebih banyak dibandingkan perempuan (26 orang). Kejadian ulkus kaki diabetik paling banyak pada kelompok usia 60-69 tahun. Rerata usia pasien ulkus kaki diabetik ialah 58,5 tahun dengan usia terendah 32 tahun dan tertinggi 87 tahun. Sebagian besar pasien masuk perawatan dengan leukositosis (46 orang; 74,1\%), kontrol gula darah tidak teratur (44 orang; $70,9 \%$ ), dan hipoalbuminemia (61 orang; $98,3 \%$ ). Terdapat riwayat merokok pada 20 orang pasien $(20,9 \%)$; hipertensi pada 22 orang pasien $(35,4 \%)$; dan dislipidemia pada 13 orang pasien $(20,9 \%)$.

Tabel 1. Karakteristik subyek penelitian

\begin{tabular}{|c|c|c|}
\hline Variabel & $\begin{array}{c}\begin{array}{c}\text { Jumlah } \\
(n=62)\end{array} \\
\end{array}$ & $\begin{array}{c}\text { Persentase } \\
\% \\
\end{array}$ \\
\hline \multicolumn{3}{|l|}{ Jenis kelamin } \\
\hline Laki-laki & 36 & 58,0 \\
\hline Perempuan & 26 & 41,9 \\
\hline \multicolumn{3}{|l|}{ Usia (Tahun) } \\
\hline $30-39$ & 8 & 12,9 \\
\hline $40-49$ & 5 & 8,0 \\
\hline $50-59$ & 18 & 29,0 \\
\hline $60-69$ & 21 & 33,8 \\
\hline $70-79$ & 6 & 9,6 \\
\hline $80-89$ & 4 & 6,4 \\
\hline \multicolumn{3}{|l|}{ Leukositosis } \\
\hline$<11.000$ & 16 & 25,8 \\
\hline$>11.000$ & 46 & 74,1 \\
\hline \multicolumn{3}{|l|}{ Hbalc (\%) } \\
\hline$\leq 7$ & 10 & 16,1 \\
\hline$>7$ & 52 & 83,8 \\
\hline \multicolumn{3}{|l|}{ Hipertensi } \\
\hline $\mathrm{Ya}$ & 22 & 35,4 \\
\hline Tidak & 40 & 64,5 \\
\hline \multicolumn{3}{|c|}{ Kontrol gula darah } \\
\hline teratur & 18 & 29,0 \\
\hline tidak teratur & 44 & 70,9 \\
\hline \multicolumn{3}{|l|}{ Merokok } \\
\hline $\mathrm{Ya}$ & 20 & 32,2 \\
\hline tidak & 42 & 67,7 \\
\hline \multicolumn{3}{|c|}{ Hiperkolesterolemia } \\
\hline $\mathrm{Ya}$ & 13 & 20,9 \\
\hline Tidak & 49 & 79,0 \\
\hline \multicolumn{3}{|c|}{ Hipoalbuminemia } \\
\hline$\geq 3,5$ & 1 & 1,6 \\
\hline$<3,5$ & 61 & 98,3 \\
\hline
\end{tabular}

Tabel 2 menunjukkan bahwa gambaran spektral Doppler pada arteri tibialis posterior ialah bifasik $(40,3 \%)$, dan arteri dorsalis pedis ialah bifasik $(41,9 \%)$ juga. Pada perfusi ditemukan $50 \%$ pasien mengalami penyakit arteri perifer (PAP); hanya $30,6 \%$ yang tidak menderita PAP. 
Terdapat $90,3 \%$ pasien memiliki ukuran ulkus $>3 \mathrm{~cm}^{2}$. Infeksi didapatkan terbanyak hanya superfisial pada subkutis $56,4 \%$; sisanya telah terinfeksi sampai fasia, otot dan tendon. Pasien dengan ulkus kaki diabetik sebagian besar (58\%) sudah mengalami infeksi berat dengan peningkatan leukosit yang tinggi saat dirawat tetapi hanya $29 \%$ pasien yang mengalami kehilangan sensorik.

Tabel 3 menunjukkan bahwa pasien dengan gambaran spektral Doppler normal lebih memiliki kemungkinan sembuh yang tinggi, sedangkan pasien dengan gambaran spektral Doppler yang tidak normal cenderung memiliki skor yang lebih jelek.

Tabel 2. Distribusi data spektral Doppler arteri tibialis posterior dan arteri dorsalis pedis serta skor PEDIS pada ulkus kaki diabetik

\begin{tabular}{|c|c|}
\hline Variabel & $\begin{array}{c}\text { Ulkus kaki } \\
\text { diabetik }\end{array}$ \\
\hline \multicolumn{2}{|l|}{ Spektral Doppler arteri tibialis posterior } \\
\hline Trifasik & $19(30,6 \%)$ \\
\hline Bifasik & $25(40,3 \%)$ \\
\hline Monofasik & $18(29,0 \%)$ \\
\hline \multicolumn{2}{|l|}{ Spektral Doppler arteri dorsalis pedis } \\
\hline Trifasik & $15(24,1 \%)$ \\
\hline Bifasik & $26(41,9 \%)$ \\
\hline Monofasik & $21(33,8 \%)$ \\
\hline \multicolumn{2}{|l|}{ Perfusi } \\
\hline Grade I, No PAD (0) & $19(30,6 \%)$ \\
\hline Grade II, PAD (1) & $31(50 \%)$ \\
\hline Grade III, CLI (2) & $12(19,3 \%)$ \\
\hline \multicolumn{2}{|l|}{ Ekstensi } \\
\hline Grade I, skin intact (0) & 0 \\
\hline Grade II, $<1 \mathrm{~cm}^{2}(1)$ & 0 \\
\hline Grade III, $1-3 \mathrm{~cm}^{2}(2)$ & $6(9,6 \%)$ \\
\hline Grade IV, $>3 \mathrm{~cm}^{2}(3)$ & $56(90,3 \%)$ \\
\hline \multicolumn{2}{|l|}{ Dalam (Depth) } \\
\hline Grade I, skin intact $(0)$ & 0 \\
\hline Grade II, Superficial (1) & $27(43,5 \%)$ \\
\hline Grade III, Fascia Muscle, tendon (2) & $35(56,4 \%)$ \\
\hline Grade IV, bone or joint (3) & 0 \\
\hline \multicolumn{2}{|l|}{ Infeksi } \\
\hline Grade I, none $(0)$ & 0 \\
\hline Grade II, Surface (1) & $13(20,9 \%)$ \\
\hline Grade III, Abscess, fasciitis, septic arthritis (2) & $13(20,9 \%)$ \\
\hline Grade IV, SIRS (3) & $36(58 \%)$ \\
\hline \multicolumn{2}{|l|}{ Sensorik } \\
\hline Grade I, No loss $(0)$ & $44(70,9 \%)$ \\
\hline Grade II, Loss (1) & $18(29 \%)$ \\
\hline \multicolumn{2}{|l|}{ Total Skor PEDIS } \\
\hline 5 & $1(1,6 \%)$ \\
\hline 6 & $13(20,9 \%)$ \\
\hline 7 & $13(20,9 \%)$ \\
\hline 8 & $16(25,8 \%)$ \\
\hline 9 & $9(14,5 \%)$ \\
\hline 10 & $6(9,6 \%)$ \\
\hline 11 & $4(6,4 \%)$ \\
\hline 12 & 0 \\
\hline
\end{tabular}


Tabel 3. Hubugan antara gambaran spektral Doppler dengan skor PEDIS

\begin{tabular}{cccc}
\hline $\begin{array}{c}\text { Gambaran spektral } \\
\text { Doppler }\end{array}$ & $\begin{array}{c}\text { Skor PEDIS }<\mathbf{7} \\
\text { Sembuh }\end{array}$ & $\begin{array}{c}\text { Skor PEDIS }>\mathbf{7} \\
\text { Sukar sembuh }\end{array}$ & $\begin{array}{c}\text { Total } \\
(\mathbf{n = 6 2})\end{array}$ \\
\hline Arteri tibialis posterior & & & \\
Trifasik & 15 & 6 & $21(33,8 \%)$ \\
Bifasik & 11 & 13 & $24(38,7 \%)$ \\
Monofasik & 0 & 17 & $17(27,4 \%)$ \\
Arteri dorsalis pedis & & & \\
Trifasik & 13 & 5 & $18(29 \%)$ \\
Bifasik & 8 & 18 & $26(41,9 \%)$ \\
Monofasik & 5 & 13 & $18(29 \%)$ \\
\hline
\end{tabular}

Karena keparahan ulkus berbentuk data ordinal maka pengujian hubungan gambaran spektral Doppler dan keparahan ulkus dianalisis dengan koefisien korelasi Spearman. Hasil analisis mendapatkan pada arteri tibialis posterior, $\mathrm{r}=-0,569$ dengan $P=0,000$; dan pada arteri dorsalis pedis, $\mathrm{r}=$ $-0,301$ dengan $P=0,017$. Hal ini menyata- kan adanya hubungan negatif antara gambaran spektral Doppler dengan skor PEDIS. Jika skor PEDIS meningkat maka gambaran spektral Doppler arteri tibialis posterior dan dorsalis pedis akan memburuk. Secara grafik hubungan antara gambaran spektral Doppler dengan skor PEDIS dapat dilihat pada Gambar 1 dan 2.

Tabel 4. Uji Korelasi Data Gambaran Spektral Doppler terhadap Skor PEDIS Ulkus Kaki Diabetik

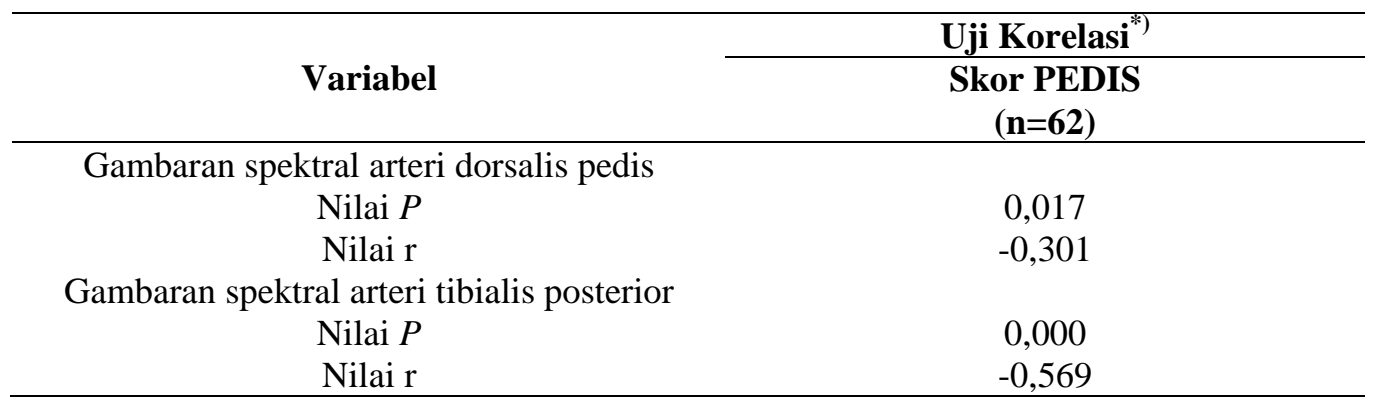

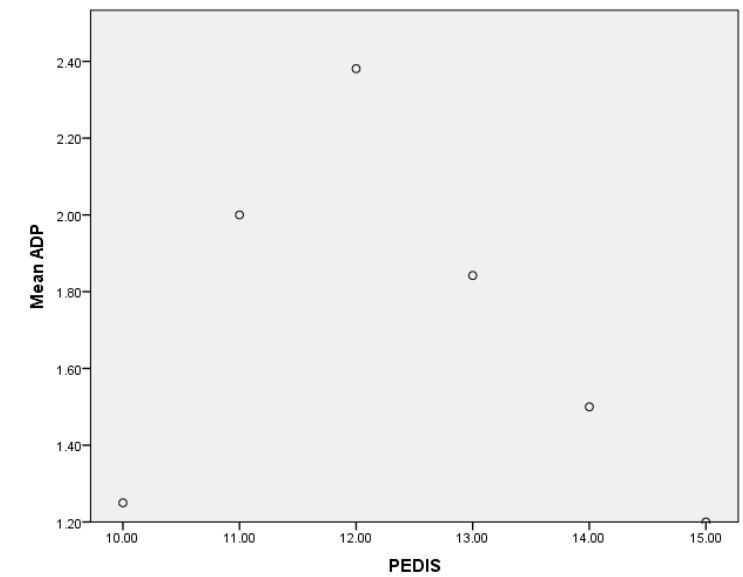

Gambar 1. Hubungan antara gambaran spektral Doppler arteri dorsalis pedis dengan skor PEDIS

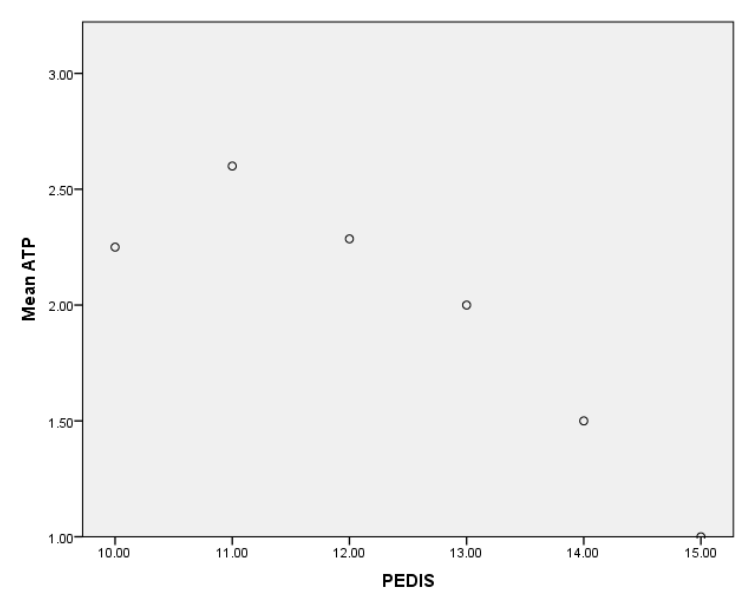

Gambar 2. Hubungan antara gambaran spekral Doppler arteri tibialis posterior dengan skor PEDIS 


\section{BAHASAN}

Ulkus kaki diabetik merupakan salah satu komplikasi yang tersering pada penyandang DM yang sangat ditakuti karena dapat menyebabkan cacat bahkan kematian. Kaki diabetik juga menjadi salah satu penyebab utama terjadinya amputasi nontraumatik pada ekstremitas inferior. Hal ini menjadi beban ekonomi tidak hanya untuk penderita namun juga untuk institusi kesehatan.

Dalam periode Agustus 2017 sampai Januari 2018 didapatkan sebanyak 62 kasus kaki diabetik dengan komplikasi ulkus di Bagian Bedah dan Bagian Ilmu Penyakit Dalam RSUP Prof. Dr. R. D. Kandou Manado. Dari jumlah tersebut didapatkan laki-laki lebih banyak dari perempuan. Data tersebut sesuai dengan acuan pustaka yang menyatakan bahwa jenis kelamin lakilaki mempunyai faktor risiko tinggi terhadap kaki diabetik. Beberapa penelitian epidemiologi ulkus kaki diabetik lainnya di Rumania, ${ }^{18}$ Sydney, ${ }^{19}$ dan Mesir $^{20}$ juga menun-ukkan bahwa kejadian ulkus kaki diabetik terbanyak pada laki-laki dengan perbandingan 2:1. Hal ini tidak sejalan dengan penelitian oleh Kristiani ${ }^{21}$ di Manado yang melaporkan bahwa jenis kelamin perempuan lebih banyak dibandingkan laki-laki.

Hasil penelitian ini mendapatkan kejadian ulkus kaki diabetik tersering pada kelompok usia 60-69 tahun dengan rerata 58,5 tahun; terendah 32 tahun; dan tertinggi 87 tahun (Tabel 1). Hal ini selaras dengan penelitian oleh Zaine et al. ${ }^{19}$ dan Nwabudike et al. ${ }^{22}$ yang melaporkan bahwa kejadian ulkus kaki diabetes tertinggi pada dekade ke-6. Berbeda dengan penelitian di Amerika yang melaporkan bahwa persentase kaki diabetik paling tinggi pada usia 45-64 tahun. Seperti diketahui, lanjut usia biasanya memiliki keterbatasan gerak, ketajaman penglihatan berkurang, dan masalah penyakit lainya. Kejadian kaki diabetik sangat tinggi pada lanjut usia karena pada usia ini fungsi tubuh secara fisiologik menurun. Rentang usia kejadian ulkus kaki diabetik di Indonesia lebih muda dibandingkan penelitian-penelitian epide- miologi serupa di luar negeri. Hal ini diperkirakan disebabkan oleh tingkat kesadaran masyarakat terhadap penyakit DM yang masih rendah. Penyandang DM sebagian besar tidak berobat teratur sehingga komplikasi dari DM itu sendiri seperti ulkus kaki diabetik terjadi lebih cepat daripada seharusnya bila kadar gula darah selalu terkontrol dengan baik.

Kontrol gula darah tidak teratur ditemukan sebanyak $70,9 \%$ dari pasien. Hal ini sangat menunjang bahwa kesadaran terhadap penyakit DM yang rendah dengan banyaknya kejadian kadar gula darah yang tidak terkontrol. Leukositosis $(74,1 \%)$ dan hipoalbuminemia $(98,3 \%)$ juga didapatkan pada pasien rawat inap di Bagian Bedah dan Penyakit Dalam RSUP Prof. Dr. R. D. Kandou. Pada penelitian di India oleh Viswanathan et al. $^{23}$ didapatkan bahwa angka infeksi kaki diabetik berkisar 7,6\% $(n=100)$ yang berbeda dengan hasil penelitian ini. Di negara berkembang seperti Indonesia, infeksi masih merupakan momok untuk penyakit kaki diabetik dan merupakan salah satu prediktor kesadaran terhadap penyakit DM yang rendah dengan banyaknya kejadian gula darah tidak terkontrol (70,9\%). Penyandang DM baru datang berobat bila sudah mengalami komplikasi DM yang berat seperti ulkus kaki diabetik yang terinfeksi dengan keadaan sistemik yang kurang baik sehingga kejadian hipoalbumin juga cukup tinggi.

Ditemukan komorbiditas seperti merokok $(32,2 \%)$, hipertensi $(35,4 \%)$, dan hiperkolesterolemia $(20,9 \%)$. yang berkorelasi kuat dengan penurunan aliran darah ke perifer pada penyandang DM. Penelitian oleh Rizk et al. ${ }^{20}$ menunjukkan angka kejadian komorniditas pada pasien ulkus kaki diabetik secara berturut-turut sebagai berikut; merokok 51,25\%, hipertensi 43,7\%, dan hiperkolesterolemia 32,5\%; kesemuanya lebih tinggi daripada hasil penelitian ini. Angka kejadian hipertensi dan dislipidemia yang lebih rendah diperkirakan berhubungan dengan perbedaan kebiasaan hidup dan pola diet populasi penelitian ini dengan populasi penelitian Rizk et al. di Mesir. 
Tabel 2 menunjukkan distribusi data gambaran spektral Doppler, masing-masing pada arteri tibialis posterior dan arteri dorsalis pedis. Gambaran spektral Doppler arteri tibialis posterior bifasik $(40,3 \%)$, demikian pula arteri dorsalis pedis bifasik $(41,9 \%)$. Hal ini menunjukan bahwa faktor iskemik pada subyek penelitian sedikit lebih dominan. Berbeda dengan penelitian di Amerika Serikat yang mendapatkan angka ulkus diabetik akibat neuropati sebesar $28,5 \%$ dan akibat penyakit vaskuler mencapai $9,5 \%$.

Sehubungan dengan skor PEDIS pada perfusi didapatkan $50 \%$ pasien grade 2 , ekstensi 90,3\% dengan ulkus berukuran $>3$ $\mathrm{cm}^{3}$, kedalaman paling banyak sampai grade $3(56,4 \%)$, infeksi telah mengalami respon inflamasi sitemik $(58 \%)$, dan sebanyak $70,9 \%$ belum kehilangan sensoriknya. Wagiu et al. ${ }^{24}$ dan Manginstar et al. $^{25}$ dalam penelitian yang terpisah mendapatkan derajat infeksi pada pasien ulkus DM paling besar sudah mencapai derajat 4 yang selaras dengan hasil penelitian ini. Skor maksimal PEDIS ialah 12, dan untuk skor $>7$ sangat erat berhubungan dengan kemungkinan sukar sembuh. ${ }^{26}$ Pada penelitian ini didapatkan bahwa pasien terbanyak ialah dengan skor $8(25,8 \%)$ diikuti skor 6 dan 7 (20,9\%), 9 (14,5\%), 10 $(9,6 \%), 11(6,4 \%)$, dan paling sedikit ialah skor $5(1,6 \%)$.

Tabel 3 menunjukkan bahwa gambaran spektral Doppler yang normal pada semua arteri ekstremitas bawah lebih memiliki kemungkinan sembuh yang tinggi, sedangkan gambaran spektral Doppler yang tidak normal cenderung memiliki skor yang lebih jelek sehingga kemungkinan sembuh sulit. Ulkus diabetik terjadi melalui dua mekanisme yaitu angiopati dan neuropati. Ulkus dapat terjadi sebagai hasil dari salah satu mekanisme ataupun keduanya. ${ }^{1,13,19,22}$ Ulkus dapat bertambah berat sesuai dengan beratnya iskemia jaringan yang pada penelitian ini diukur dengan menggunakan Doppler.

Hasil penelitian ini menyatakan terdapat hubungan bermakna antara gambaran spektral Doppler dengan skor PEDIS.
Makin tinggi skor PEDIS makin buruk gambaran spektral Doppler. Temuan ini menyokong bahwa handheld vascular Doppler dapat digunakan untuk membantu penentuan terapi dan pengobatan pada pasien ulkus kaki diabetik khususnya di RS daerah dengan keterbatasan fasilitas canggih seperti USG Doppler.

Secara statistik derajat iskemi, dimensi ulkus, infeksi, dan sensorik dapat memengaruhi terjadinya ulkus diabetik. Perhatian khusus harus diberikan pada penderita kaki diabetik untuk mencegah terjadinya ulkus dengan mengontrol faktor-faktor risiko, mengidentifikasi kaki berisiko dan edukasi pada penderita DM. Pencegahan terhadap amputasi ekstremitas nontraumatik akibat DM harus menjadi prioritas utama yaitu dengan melakukan pemeriksaan sirkulasi pada ekstremitas inferior terutama pada penyandang DM yang sudah lama dengan atau tanpa faktor risiko kardiovaskuler. Untuk alasan ini maka dianjurkan adanya monitoring kaki pada penyandang DM seperti disebutkan di atas.

Limitasi penelitian ialah tidak dilakukannya analisis komorbiditas subyek penelitian dan pengelompokan etiologi yang lebih spesifik untuk menepis kemungkinan adanya kondisi medis pembuluh darah yang memengaruhi gambaran spektral Doppler.

\section{SIMPULAN}

Berdasarkan hasil penelitian ini dapat disimpulkan bahwa terdapat hubungan bermakna antara gambaran spektral Doppler dengan skor PEDIS. Makin tinggi skor pedis maka makin buruk gambaran spektral Doppler.

\section{SARAN}

Dapat dilakukan penelitian lebih lanjut untuk mengembangkan hasil penelitian ini dengan tujuan memberikan gambaran peranan handheld Doppler pada arteri ekstremitas inferior sebagai salah satu alat diagnostik untuk mendeteksi PAP secara dini pada pasien-pasien DM, baik yang dengan maupun tanpa komplikasi, dan kemudian dijadikan sebagai salah satu parameter prediksi prognosis serta evaluasi 
respon pemberian terapi terhadap PAP.

Perlu dilakukan edukasi terhadap penyandang DM mengenai komplikasi iskemi perifer dan neuropati iskemi pada kaki diabetik untuk mencegah komplikasi yang lebih lanjut.

Disarankan untuk penelitian selanjutnya dengan menggunakan metode penelitian yang lebih baik (case control) dan proporsi jumlah sampel yang seimbang untuk tiap derajat ulkus dan analisis komorbiditas serta etiologi yang lebih spesifik.

Diharapkan penelitian ini dapat menjadi titik tumpu untuk penelitian-penelitian berikutnya sehingga mutu peningkatan pelayanan terhadap penderita kaki diabetik bisa lebih ditingkatkan.

\section{DAFTAR PUSTAKA}

1. Alavi A, Sibbald RG, Mayer D, Goodman L, Botros M, Armstrong DG, et al. Diabetic foot ulcers: Part I. Pathophysiology and prevention. J Am Acad Dermatol. 2014;70(1):1 e1-18.

2. Wang AH, Xu ZR, Ji LN. Clinical characteristics and medical costs of diabetics with amputation at central urban hospitals in China. Zhonghua Yi Xue Za Zhi. 2012;92:224-7.

3. Lipsky BA, Weigelt JA, Sun X, Johannes RS, Derby KG, Tabak YP. Developing and validating a risk score for lower-extremity amputation in patients hospitalized for a diabetic foot infection. Diabetes Care. 2011;34: 1695-1700.

4. Martinsmendes D, Monteirosoares M, Boyko EJ, Ribeiro M, Barata P, Lima $J$, et al. The independent contribution of diabetic foot ulcer on lower extremity amputation and mortality risk. J Diabetes Complications. 2014;28:632-8.

5. Monteirosoares M, Boyko EJ, Ribeiro J, Ribeiro I, Dinisribeiro M. Risk stratification systems for diabetic foot ulcers: a systematic review. Diabetologia. 2011;54:1190-9.

6. Yusuf S, Kasim S, Okuwa M, Sugama J. Development of an enterostomal therapy nurse outpatient wound clinic in Indonesia: a retrospective descripttive study. Wound Practice \& Research. 2013;21(1):41-7.
7. Yusuf S, Okuwa M, Irwan M, Rassa S, Laitung B, Thalib A, et al. Prevalence and risk factor of diabetic foot ulcers in a regional hospital, Eastern Indonesia. Open Journal of Nursing. 2016;6:1-10.

8. Guariguata L, Whiting DR, Hambleton I, Beagley J, Linnenkampo U, Shaw JE. Global estimates of diabetes prevalence for 2013 and projections for 2035. Diabetes Res Clin Pract. 2014; 103(2):137-49.

9. Treece KA, Macfarlane RM, Pound N, Game FL, Jeffcoate WJ. Validation of a system of foot ulcer classification in diabetes mellitus. Diabet Med. 2004; 21:987-91.

10. Karthikesalingam A, Holt PJ, Moxey P, Jones KG, Thompson MM, Hinchliffe RJ. A systematic review of scoring systems for diabetic foot ulcers. Diabet Med. 2010;27:544-9.

11. Schaper NC. Diabetic foot ulcer classification system for research purposes: a progress report on criteria for including patients in research studies. Diabetes Metab Res Rev. 2004;20 Suppl 1:S90S5.

12. Chuan F, Tang K, Jiang $P$, Zhou B, Ho X. Reliability and validity of the perfusion, extent, depth, infection and sensation (PEDIS) classification system and score in patients with diabetic foot ulcer. Fabio Santanelli, di Pompeo d'Illasi, Academic Editor. PLoS One. 2015;10(4):e0124739.

13. Oyibo SO, Jude EB, Tarawneh I, Nguyen HC, Armstrong DG, Harkless LB, et al. The effects of ulcer size and site, patient's age, sex and type and duration of diabetes on the outcome of diabetic foot ulcers. Diabet Med. 2001;18:1338.

14. Oyibo SO, Jude EB, Tarawneh I, Nguyen HC, Harkless LB, Boulton AJ. A comparison of two diabetic foot ulcer classification systems: the Wagner and the University of Texas wound classification systems. Diabetes Care. 2001;24:84-8.

15. Monteirosoares M, Vazcarneiro A, Sampaio S, Dinisribeiro M. Validation and com-parison of currently available stratifica-tion systems for patients with diabetes by risk of foot ulcer development. Eur J Endocrinol. 
2012;167:401-7.

16. Reynolds T. Disease prediction models aim to guide medical decision making. Ann Intern Med. 2001;135:637-40.

17. Adhiarta. Penatalaksanaan kaki diabetik. Artikel. In: Forum Diabetes Nasional V. Bandung: Pusat Informasi Ilmiah Departemen Ilmu Penyakit Dalam FK Unpad, 2011.

18. Bishara RA, Taha W, Akladious I, Allam MA. Ankle peak systolic velocity: new parameter to predict nonhealing in diabetic foot lesions. Vascular. 2009; 17(5):264-8.

19. Zaine MH, Burns J, Vicaretti M, Fletcher JP, Begg L, Hitos K. Characteristic of diabetic foot ulcers in Western Sidney, Australia. Journal of Foot and Ankle Research. 2014;7:39

20. Rizk MN, Ameen AI. Comorbidities associated with Egyptian diabetic foot disease subtypes. The Egyptian Journal of Internal Medicine. 2013;25(3):154-8.

21. Kristiani AL, Sumangkut R, Limpeleh $\mathbf{H}$. Hubungan Ankle Brachial Index dengan keparahan ulkus pada penderita kaki diabetik. JBM. 2015;7(3):171-7.

22. Nwabudike LC, Tirgoviste CI. Risk factors and clinical characteristic for foot ulcers in patients with diabetes in Bucharest, Romania. Proc Rom Acad. 2008;1-2:49-52.

23. Wagiu AMJ, Sumangkut R, Sapan H, Waworuntu LAJ. Perbandingan efektifitas asam perasetik dan feracrylum pada pola kuman ulkus diabeti. JBM. 2016;8(1):51-7.

24. Manginstar C, Sapan H, Sumangkut R, Ngantung J. Uji sensitivitas cuka 5\% hydrogen peroksida 3\% dan asam perasetik terhadap pola kuman penderita ulkus diabetik di RSUP Prof. Dr. R. D. Kandou [Karya Akhir]. Manado: Universitas Sam Ratulangi; 2013.

25. Viswanathan $\mathrm{V}$, Thomas $\mathrm{N}$, Tandon $\mathbf{N}$, Asirvatham A, Rajasekar S, Ramachandra A, et al. Profile of diabetic foot complications and its associated complications-a multicentric study from Indoa. J Assoc Physicians India. 2005;53:933-6.

26. Chuan F, Tang K, Jiang $P$. Realibility and validity of PEDIS classification and score in patient with diabetic foot ulcer. J Foot Ankle Surg. 2004;43:20913. 